\title{
The Polyvalent Qadamgāh Imām 'Alī In Hyderabad, Sindh
} A Preliminary Study in Relics, Political Power, and Community Setup

\author{
Michel Boivin \\ Director, Centre for South Asian Studies, National Centre for Scientific Research, \\ (CNRS-CEIAS), Paris, France \\ michel.boivin@ehess.fr
}

\begin{abstract}
In the early twentieth century, scholars such as I. Goldziher reported that India was characterized by a large number of bodily relics relating to Muhammad that were venerated. But another issue was ignored: the worship of the footprints of the first Shi'ite Imam, 'Alī. This contribution offers an analysis of the various political and social issues that the Qadamgāh Imām 'Alī of Hyderabad, Sindh (Pakistan), has embodied since its installation at the beginning of the nineteenth century.
\end{abstract}

\section{Keywords}

relics - footprints - Hyderabad Sindh - Shi'ism - pị - imāmbārā/imāmbārgāh - Mowlā jā Qadam/Qadamgāh Imām 'Alī - Sufism - dargāh

In a recent book on devotional technologies, Barry Flood has shown that the veneration of relics has been around since the beginnings of Islam (Flood, 2019). They were first centered around representations of Mecca's holy places, starting with the Ka'aba. Within the religious complex that it constitutes, one can find the Ibrahim Maqam, "the place of Ibrahim," where the footprints attributed to the Prophet Ibrahim, who is also said to have built the Ka'aba, are kept in stone. Consequently, the veneration of footprints is tied to the most sacred place of Islam. The footprints of other sacred characters are also venerated, including those of the Prophet Muhammad.

The cult of sacred footprints is indeed widespread among South Asian Muslims, and the places where they are kept bear different names: the qadam sharif ("sacred footprint") usually houses the footprints of Muhammad, while the Mowlā jā Qadam (Footprints of the Lord), Shāh jā Qadam (Footprints of the Master) or Qadamgāh Imām 'Alī (Imām 'Alī's Footprint Shrine) refer to the footprints of the first Shi'ite Imam, 'Alì. The word qadam literally means "foot" in Arabic, and in Sindhi, by metonymy, "the place of print left by the foot." Qadam sharif thus means literally "sacred foot," and by extension "sacred footprints." The word qadamgāh used in Urdu comes from Persian, and it means the place where the foot(print) is kept.

While Muḥammad's qadamgāh has received academic interest (Ganem, 2006; Hasan, 1993; Khawajah, 1996; Welch, 1993), in a South Asia Muslim context, it is amazing that other footprints have been neglected by specialists, especially 'Alì's footprints. Nile Green was probably one of the first scholars to draw attention to 'Ali's footprints, which are venerated as relics in several areas of South Asia. ${ }^{1}$ He recalled that, in addition to 
the imāmbārās, ${ }^{2}$ these "secondary sanctuaries" have been key players in the rooting and "acculturation" of Islam in South Asia. They were able to play a fundamental role in the conversion of populations to Islam, like in Bengal. For him, the qadamgāhs have helped shape the sacred geography of Shicism in the Indian subcontinent. Because some qadamgāhs were directly imported from Arabia; they rooted the sacred history of Islam in Indian soil. They therefore played a leading role in the construction of the Muslim space.

This paper intends to address several issues related to the qadamgāh by focusing on a site which is located in Hyderabad, in Sindh Pakistan. Since the end of the eighteenth century, Sindh had been ruled by a Shi'i dynasty, the Tālpūrs (1783-1843), and in the colonial period (1843-1947) a Shicite princely state had subsisted in the northeastern part of the province, the State of Khairpur. Working on the material culture of Shicism in Sindh requires dealing with several interwoven processes. The first one is probably the most intricate: it concerns the close intertwining of Sufi and Shicite cultures. In another publication, I have shown how this harmonious marriage has been elaborated in Sindhi Sufi poetry (Boivin, 2020). Here I want to shift the issue to material culture through the study of the qadams.

This article is based on the argument that the qadams are a subcategory of bodily relics, whose functions are both similar and different. Thus, taking the Hyderabad qadamgāh as a case study, I intend to understand why this specific Muslim relic has spread in the area under study, how it manages to compete with other devotional sites hosting relics, in other words how it was located in the devotional landscape of Sindh, and what its place is in footprints worship that is so widely spread in the Indic religions, where the foot as relic is known as $p \bar{a} d a$, from Sanskrit, or $p \bar{a} d u k \bar{a}$. The polyvalence of the qadam comes from a number of characteristics that this contribution wishes to disentangle.

Furthermore, I intend to introduce the Qadamgāh Imām 'Alī, the footprints of the Lord, who is 'Alī, as a devotional site that transcends religious (Muslim, Hindu, Christian etc.) and sectarian (mostly Sunni and Shicite) affiliations. Many different words are used by scholars for the qualification of the interreligious use of sacred sites, such as "ambiguous"(Bellamy, 2011). I prefer the more neutral word "complex" because I consider that every case study shows many different processes of the intertwining of religious repertoires. Moreover, these sacred sites do not express any ambiguity at all for believers. The different footprints belonging to Muslim characters show a number of differences, in terms of size, drawing and carving. We can find three different types: 1 . Absence of any trace, which does not prevent the devotees from worshipping at a place like Mowlā jā Qadam; 2. A loose shape of imprint, usually roughly carved in stone; and 3. A clear imprint of feet. Such differences can be found in other religions (Kinnard, 2014; Nugeteren, 2018).

The first and second parts focus on the Qadamgāh Imām 'Alī, 'Alī's footprints, which are installed in Hyderabad, ${ }^{3}$ the former capital of the state of Sindh before the British conquest in 1843. I shall start with the historical pre-conditions that prevailed in the transfer of the Qadamgāh to Hyderabad, and how the Tālpūr Kings have sought to make them a new devotional pole in the capital and the state; an attempt that would be annihilated by the British conquest. In the second section, the present situation of the site will be explored, by highlighting the demographic change in Hyderabad resulting from the large influx of migrants from India from 1947 onwards, when it was renamed Qadamgāh Imām 'Alī. It will also underly how the rituals are interwoven with the Sufi repertoire, a conversation that is reinforced by the study of the processional pathways. Finally, the third part deals with the qadam as a religious object, the identification of

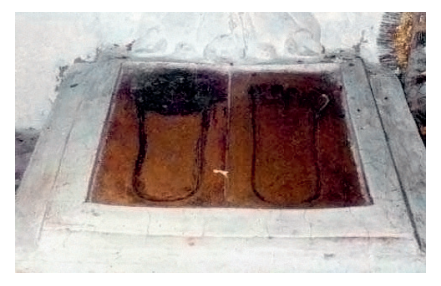

FIGURE 1

'Alī's footprints known as Mowlā jā Qadam or Qadamgāh Mowlā 'Alī, Makkli (Thatta)

(C) SYED MEHAR ALI SHAH KAZMI

HTTPS://FR-FR.FACEBOOK. COM/909051582526274/ Pнотоs/A.947110015387097/ $1367716536659774 /$ ?TYPE $=3$ \&THEATER 
the kind of relic. Emphasis will be placed on the experiences it causes, and for that last section, my main thesis will be that the object has a specific status, which I will describe as "liminal".

While most works on relics focus on their materiality, on their use in a process of recollection, this chapter is more interested in the changing socio-political roles that have been attributed to a specific category of relics: 'Alī's footprints. They are a very specific type of relics, as they refer to a main component: the body, which is absent. It is a fact that in South Asia all religions practiced have included the worship of footprints. If we confine ourselves to the Indus Valley, we find Buddha's footprints in Swat or, closer to Sindh, Guru Nanak's footprints in Hinglaj, ${ }^{4}$ proof that he must have stopped there on his way to Mecca. Furthermore, Sindh still hosts a number of Buddhist stūpas, whose main function is that of a reliquary.

A main characteristic is what Karen Ruffle calls the "presence of absence", an expression she uses for different relics, including footprints that are used in the Moharram rituals in Hyderabad, the Deccan (Ruffle, 2017). I found this expression heuristic for the qualification of the footprints. I indeed consider that - unlike other types of relics that may have been, and usually have been brought from other places, be it a hair, or a shirt footprints unambiguously indicate the passage of a sacred figure through a place. This mark of passage instantly produces the sacralization of a space. Having said this, it should be noted that some of the footprints can be moved, as in the case of the Mowlā jā Qadam in Hyderabad. But it remains that here again, these footprints have an immediate effect on the believer who, by looking at them, finds himself in the presence of the sacred figure, despite his absence.

For Muslims of South Asia, the Qadam Rasūl shrine (1530) at Gaur, in Bengal, is the earliest extant state sponsored reliquary shrine of its type in pan-Indian regions, which as its name implies, was a commemorative structure that was devoted to the enshrinement of a footprint of Muhammad (Ganem, 2006: 18). Soon after it was erected, Sulțān Ibrāhīm Quṭubshāh of Golconda built a sanctuary on the Koh-e Mowlā 'Alī to host 'Alī's handprints in late sixteenth century, and the sultans used to perform the pilgrimage every year. The place was located near Hyderabad, the Deccan, and from 1687 onward, when it came under the control of the Sunni rulers, the nizäms have carried on with the yearly pilgrimage (Green, 2010: 61).

\subsection{Relics as Political Alliance between the Qajars and the Tälpūrs}

This section aims to contextualize the successive shiftings, both physical and symbolic, of the Mowlā jā Qadam, from its installation in Hyderabad to its partition. For this reason, I must begin with the very particular period of the eighteenth century in South Asia. Indeed, it was a very turbulent period, for two main, but not unique reasons. On the one hand, it saw the gradual collapse of the Mughal Empire, which had been the dominant power since the sixteenth century. After the death of Aurangzeb in 1707, the Mughal order slowly began to break down, allowing its provinces to gain more and more autonomy. On the other hand, this decay of the Mughal Empire opened the territory to outside invasions, in particular those of Nādir Shāh in 1739, and, next, of Ahmad Shāh Durrānī who invaded the Mughal Empire seven times from 1748 to 1764 , the last corresponding to the very date that the Mughal emperor was also defeated by the army of the East India Company at Buxar. Buxar was the fatal blow, since it consecrated the defeat of the Mughal emperor, and, at the same time, consolidated British dominion over northern India. 
Sindh was one of those territories that managed to take advantage of the break-up of the Mughal Empire, to become a successor state. The Kalhoṛās were the governors of Sindh, and Aurangzeb bestowed upon Miyyān Yār Muhammad Kalhoṛo (d. 1719) the title of nawāb. ${ }^{5}$ The tribal organization of Sunni Muslims was coupled with Sufi brotherhood-like communities that created a spiritual bond between the tribesmen and the head (sardar) of the tribe (qabïlo). The Kalhorāa army was defeated by Nādir Shāh and after Aḥmad Shāh Durrānī's invasions, Sindh was under the sovereignty of the Afghan emperors. For some time, a main part of the Kalhorā army was made of Baluchi soldiers, belonging to many different tribes.

These Baluchis were vassals to the Kalhorāas, but they were quick to rebel if they felt they were being mistreated. A number of times, the Kalhoraa rulers had to call on Tīmūr Shāh Durrānī, Ahmmad Shāh's son, to help them restore order. Finally, in 1783, the Tālpūrs, a Baluchi tribe, defeated the Kalhoṛās at the Battle of Halani and since then, they became the new rulers of Sindh. Contrary to the Kalhoṛās, the Tālpūrs were Baluchis instead of Sindhis. While their predecessors had been supported by the Durrānīs of Afghanistan, the Tālpūrs had to find new allies, knowing that the Mughal Empire was under British control. Contrary to the Kalhoṛās who were Sunnis, the Tālpūrs were Twelver Shicites. They approached the rulers of Persia, the Qajars, who had acceded to power for their part in 1786. As we shall see, the Mowlā jā Qadam was originally the materialization of an alliance between the Qajars and the Tālpūrs, as well as the making of a sacred thread with the sacred Shici sites from Persia, especially the Qadamgāh of Imām Reżā settled near Nishapur. ${ }^{6}$

The Mowlā jā Qadam was brought from Persia to Sindh, when Fatḥ 'Alī Shāh was ruling the first country, and Mīr Fateh 'Alī Khān the second, between 1786 and 1795, when Mīr Fateh 'Alī Khān passed away. ${ }^{7}$ There are other traces that demonstrate that a rapprochement took place between Qajar Persia and Tālpūr Sindh. The first author, for example, who was specialized in writing elegies on the Karbala tragedy, known as marsìyas in Sindhi, was Sābit 'Alī Shāh (d. 1224/1810) (Boivin, 2020). He was born in Multan, in South Punjab, but settled in the holy city of Sehwan Sharif, in Sindh, with his father Madar 'Alī Shāh. He was a Sayyid ${ }^{8}$ who wrote poetry in Persian, Urdu and Sindhi, and was patronized by the Țalpūrs. He lived at the court of Hyderabad. It was because of the patronage of the king that he was able to make a pilgrimage to Karbala, in Iraq, and the shrines of all the Imams (Boivin, 2020). In 1805, the new mir (king) of Hyderabad, Mīr Ghulām 'Alī Khān, sent him to the king of Persia, Fatḥ 'Alī Shāh Qājār (d. 1834) as an ambassador.

The Mowlā jā Qadam was brought to Hyderabad, a city that was built by the last Kalhorāa king, and that the Tālpūrs had kept as their royal capital. The Tālpūrs lived inside the walled city, known as the Fort (Qila), itself divided into two parts: the Pakka Qila, or "the fort made of baked bricks," and the Kacha Qila, "made of unbaked clay bricks." The Kacha Qila was smaller and it was built around a shrine devoted to Makka'ī Shāh, a local saint. The Tālpūr princes lived in the Pakka Qila, with their courts and harems. The Pakka Qila also included several mosques, royal palaces, a cemetery and a park. After the fall of the Tālpūrs in 1843, many Hindu families settled in the fort. The main entrance of the Pakka Qila was located to the north, and it overlooked a large roundabout called Qila Chowk, where, during the riots of the 199os, many would lose their lives. ${ }^{9}$

Mīr Fateh 'Alī Khān Tālpūr built a special room inside the Pakka Qila for these holy footprints, next to a mosque for minor pilgrimage (ziy ärat). ${ }^{10}$ After the canonical prayer (namāz) on Thursday night, the women of the Tālpūr family used to worship these footprints. Consequently, the use of the sacred space was exceptionally private, and, apparently, the Tālpūr family considered them a private gift from the shāh of Persia. The common people were only allowed to see the footprints on 'Id of Nawroz. Nawroz, the 
FIGURE 2

Sindh with main cities and places

(C) MICHEL BOIVIN FROM

GOOGLE MAP

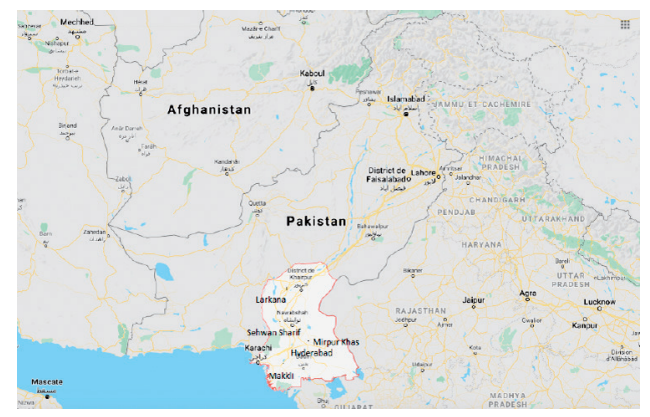

"New Day" is an important festival among the Muslims of South Asia, for both Sunnis and Shicites. In Persia, it was a celebration of the renewal of nature and the coming of Spring. In Qajar Persia (1779-1925), the shäh received guests consisting of kinsmen, military and civil officials, leading religious figures, tribal chiefs, poets, heads of various guilds, and, increasingly, foreign notables. The same protocol was possibly adopted by the Tālpūrs in Sindh. Furthermore, the transportation of the Mowlā jā Qadam to the Tālpūr capital can be given a strong political meaning. From early on in the history of the Muslim world, sacred relics were seen as a determining factor in the process of legitimizing a new political power (Meri, 2010).

\subsection{Making a Shici Devotional Pole in Hyderabad}

It was in a later period that the last ruler of the Tālpūr dynasty in Hyderabad, Mīr Nāsiir Khān Tālpūr (r. 1829-43), built a shrine for the Mowlā jā Qadam and put the stones on display. The story goes that the shrine was built at the request of the people, and that it was initially open the general public. This probably took place around the time when the Mowlā jā Qadam left the Pakka Qila, the fort from where the Tālpūrs ruled Sindh. But the new location, which is still the same today, was very close to the Qila, if not leaning against it, and to another important Sufi shrine: Pīr 'Abd al-Waḥab Jīlānī, devoted to a descendant of 'Abd al-Qādir al-Jīlānī, to whom I shall return. Notwithstanding, the consequence of this transfer was the creation of a new devotional pole that handled both the Sufi and Shicite repertoires which, although physically separated since they were located in two different sites, allowed easy passage from one to the other.

It is amazing that no English source refers to the Mowlā jā Qadam. It should be pointed out that the policy of patronage of Shicite constructions by the Tālpūrs, like in other Shilite states of India, as we shall see below, focused on imāmbārāas, as indicated by the construction of the imāmbārās in Hyderabad, Khairpur, Kot Diji and other places. This type of building indeed played a key role in the expression of Shicite devotion, especially during the celebrations of Moharram. It is where the holy relics that are paraded around during the commemoration of the martyrs are stored, and it is here that the stories of the tragedy are also told by the $z \bar{a} k i r s$ (preachers). In Sindh, a specific term is used to designate them: pir (not to be confused with the Sufi master or pir). The pir can be just a simple platform that houses the Shi'ite 'alams (standards), without any real building. Now, it is interesting to note that in his book on Hyderabad, Qammaruddin Bohra classifies the Mowlā jā Qadam not as a pir, although some of the functions performed are similar to those performed in a pir, but as a dargāh, a term which is usually reserved for the Sufi shrines in Sindh (Bohra, 2000: 53, 59).

Beyond a political alliance with the Qajars of Persia, we can surmise that the Tālpūrs aimed to create a new devotional pole, that would be attached to the dynasty. It is likely that this state policy was later imitated at a local level by Shicite feudal lords, who were often involved in the management of Sufi mausoleums. With the creation of a Shicite 
devotional pole they may have sought to achieve several objectives. First, it may have served to strengthen the supremacy of the Tālpūrs of Hyderabad over its two cousins from Khairpur and Mirpur Khas, knowing that Sindh was a confederation of three states. ${ }^{11}$ Second, it is possible that by creating what might be likened to a dynastic mausoleum, the king may have attracted the Sindhis to this place of worship, whereas previously they visited the Sufi sites which were always controlled by powerful families of Sindhi Sayyids.

In other words, this foundation could have contributed to a centralization of the state, to the detriment of the feudal rulers who managed the Sufi dargāhs, but the British were not going to allow this to happen. So far, we have focused on the import of 'Ali's qadams from Qajar Persia as a seal of political alliance. Mutatis mutandis, the presence of the qadams may have enabled the Tālpūrs to consolidate their authority, much like Shāh 'Abbās did after he had taken over Mashhad from the Uzbeks at the end of the sixteenth century. Next to the holy city, which he had restored and enlarged, the presence of the Qadamgāh Imām Reżā, the eighth Imam of the Twelver Shi'ites, had helped to build a sacred route from Isfahan to Mashhad, and to impose his power over this territory of Khurasan (Ganem, 2006: 252-3).

Lastly in Sindh, by erecting a "Najaf-e Sindh,"12 the Tālpūrs were also seeking to create a devotional pole, centered around 'Alì since they were Shi'ites, to counterbalance the policy of the Kalhorāas that had been marked by the construction of Sufi mausoleums, starting with that of Shāh 'Abd al-Lațîf in Bhit Shāh. This shrine was built by Ghulām Shāh Kalhoṛo in 1754, two years after the Sufi poet's death. Ghulām Shāh Kalhoṛo built other Sufi dargāhs, such as Miyyān Nūr Muḥammad's in Nawabshah in 1758, and Shāh Bahāro in Larkana, in 1774. It is thus relevant to argue that this competition for symbolic power was embodied in the construction of sanctuaries, which, moreover, encapsulated territories. The royal authority was, as a consequence, sacralized. The Tālpūrs were looking for an alternative devotional building and site, since the Kalhorāa had appropriated the construction of the Sufi dargāhs. For this to happen, the Tālpūrs had to strengthen their Shicite networks in Persia and India, at a time when Shicite piety was booming.

From 1947 onwards, when migrants from India, known as the Mohājirs, came to Sindh, the repertoire that dominated the local religiosity was that of a vernacular Sufism, to which both Sindhi Muslims and Hindus of all faiths subscribed. Consequently, in the competition between Sindhis and Mohājirs for the domination of the city of Hyderabad, negotiations between different religious repertoires played a prominent role. My hypothesis is that the Mawlā jā Qadam represented a crucial stake in the showdown between the Sindhis and the Mohājirs, more than a vector for the integration of the Mohājirs in the urban landscape. In what follows, I will demonstrate that, although the onomastic change of the site unambiguously indicates its coming under the control of the Mohājirs, as explained below, the ritual practices show a resilience of the vernacular Sufi substratum of Sindh.

\subsection{Partition and the "Mohäjirization" of Hyderabad}

In 1947, after the British left, South Asia went through a very traumatic event, known as the partition. Two Nation-States were born from it, India, and Pakistan, a country created to house the Muslim population of the former British Empire of India. Millions of people migrated from one country to the other, and vice versa. Before the partition, Hyderabad was inhabited by a Hindu majority, but most of them left for India, and 
simultaneously, Muslim migrants arrived from India. In 1951, i.e. four years after the partition, the migrants in Hyderabad numbered 160,000 on a total of 240,000 inhabitants (Verkaaik, 1994: 95). The migrants that were called Mohājirs by the Sindhis mostly came from North India, and they spoke Urdu. The majority belonged to the educated middle classes. For the Sindhis it was logical to give them the administrative positions the Hindus had left.

The area around Qila Chowk (see fig. 6. b and 6. c) became a heteregenous area. In October 1950, riots broke out during the 'Ashūrā' procession between "migrants" and Sindhis, starting with rumors of Sindhis kidnapping "migrant" children. There were also rumors of Shicis kidnapping Sunni boys for their blood as a necessary ingredient for the rice dishes distributed during 'Ashūrāe. Sindhis and Mohājirs accused each other of being predominantly Shi'is (Verkaaik, 1994: 101). Maybe the worst confrontations between Sindhis and Mohājirs took place in May 199o, near the Pakka Qila, the political center of the Tālpūrs, which had been built by Kalhoṛās in 1768 .

The argument I would like to make here is that the riots between the Sindhis and the Mohäjirs from the 1950s onwards were the results of competition between these groups, especially for the control of the Mowlā jā Qadam. To control it, the Mohājirs had to deal with the entrenchment of Shici culture in the Sufi paradigm. It is the relationship between Shici cultural elements and the Sufi framework that we will examine next.

\subsection{The Setup of the Present-Day Qadamgāh}

Before the partition of South Asia, this place was known in Sindhi language as "Mowlā jā Qadam" (Footprints of the Lord), but with the passage of time it became known by its name in Urdu language, "Qadamgāh Imām 'Alī" (Footprints of Imam 'Alī)..$^{13}$ It is said that the visitors and devotees did not only come from Pakistan, but also from India, Afghanistan and many other countries, to pay tribute to the hero of Islam. The relics related to 'Alī are the most numerous. According to Oskar Verkaaik, in the 199os, 'Alī "has left the imprints of his knees, hands, and forehead while praying" (Verkaaik, 2004: 91). Today, we can find the prints of two hands, two feet and knees, the forehead and nose.

The veneration of 'Alī is reinforced, so to speak, by the footprints of animals associated with him, such as the footprints of a lion and his horse. It is very important to understand the meaning of this accumulation of relics related to 'Alī and his family members. Many sacred things associated with the shrines of Imam 'Alī, Imam Husayn, and 'Abbās 'Alamdār are kept in separate rooms of the shrine of Qadamgāh Imām 'Alī. A few pebble stones of Samarra are also kept in the shrine. Apart from the footprints of Imam 'Alī, there is a replica of his Shabīh Mubārak where people come to pay hommage, also known as Zarīh Mubārak. ${ }^{14}$

With the pebble stones of Samarra, the Qadamgāh Imām 'Alī is finally enshrined in a symbolic network with three polarities in relation to the Shicite shrine cities of Iraq known as the 'atabāt: Najaf, the location of 'Alī's tomb; Karbala through the relics related to Husayn, and his slaughtered family and companions; and Samarra, where the tomb of the tenth Imam, 'Alī al-Hādī (d. 868) and the eleventh Imām, Hasan al-'Askarī (d. 874) can be found. From the 'atabāt, only one city was still not mentioned here: Kazimayn, where the tombs of the seventh Imam, Musā al-Kāzem, and the ninth Imam, Muhammad al-Taqī, are located.

Two additionnal observations should be made. Another reference to Hasan al-'Askarī is expressed through the Chup Ta'ziya, a procession organized in his memory, as we shall see below. There is also another strong connection to Karbala. In South Asia, most cities, towns, and villages with a Shicite community have a "Karbala." This is a space where events commemorating the tragedy of Karbala are organized. Once more, as we 

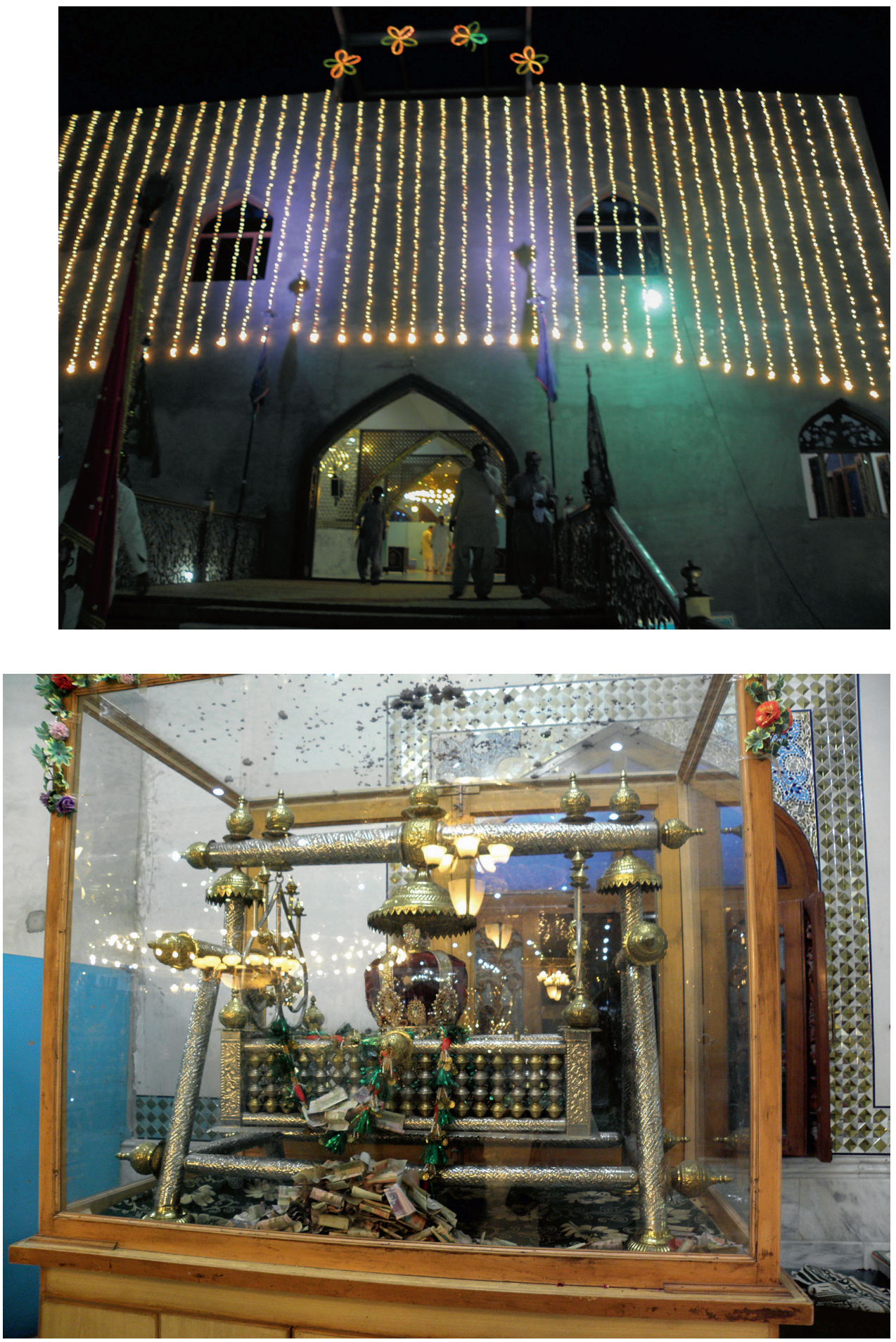

shall see below, many processions work as connections between the Qadamgāh Imām 'Alī and the Karbala of Hyderabad, called Karbala Dadan Shah.

Other Shi'ite sacred characters related to Karbala are venerated. There is 'Abbās 'Alamdār's zarịh. Close to the zarịh is kept the jhūlo (cradle) of 'Alī Asgiar ${ }^{15}$ that is made from metal. A wooden cradle of 'Alī Asg̉ar is kept in the Zarīh Mubārak of Imam Husayn at Kot Diji that was made by Mīr Fā’iz Muhammad, who was the ruler of Khairpur State between 1894 and 1909. In Hyderabad, a few valuable objects are kept at the Zarī Mubārak that were donated by the royal Tālpūr family. This is the second largest Zarīh Mubārak in Sindh after Khairpur. The Zarịh Mubārak of Kot Diji16 is only visited by the
FIGURE 3

Exterior of Qadamgāh Imām 'Alī, Hyderabad

(C) MICHEL BOIVIN, 2013

FIGURE 4

'Alī Asğar's jhūlo in Qadamgāh Imām 'Alī, Hyderabad

(C) MICHEL BOIVIN, 2013 
royal family members of the Tālpūr dynasty. It is close to the royal palace and because of security reasons only members of the royal family can access the shrine. The general public can only visit the Zarīh Mubārak at Khairpur, which was also built by the Tālpūr rulers.

The Mowlā jā Qadam was initially the name given to a building whose function was to house the footprints of 'Alì carved into a big stone. Throughout the years, many other relics were added as a kind of intention to re-create the whole dramatic process of the Battle of Karbala, and to insert the Qadam into the sacred network of the 'atabāt. This reliquary enlargement of the site corresponds to the post-Partitionist period, during which a significant migration of Mohājirs, often familiar with the Shicite culture of Awadh, ${ }^{17}$ sought to find their place in local society, but instead tried to impose their power over the local inhabitants, the Sindhis. Through the relics preserved in Qadam, connections are built with three major Shicite holy places: Najaf through 'Alī; Karbala through Husayn, 'Abbās and 'Alī Asğar; and Samarra with the stone pebbles. These connections reinforce the symbolic power of Qadam as a regional Shicite pole, even beyond Sindh. However, as we shall see, local religious paradigms survived this change.

\subsection{The Qadamgāh between Shici Repertoire and Sufi Setup}

The Sufi culture of Sindh is performed in the dargāhs, the name given to the structures, which were built to cover a saint's tomb. The visitation of a dargāh is known as a ziyārat and most often seen as a substitute for the hajj, the canonical pilgrimage to Mecca. The dargāhs are under the control of Sufi brotherhoods, which are generally led by powerful landowners. Different categories of society attend the ziyārat, but it is clear that most of the pilgrims belong to the lower middle or destitute social classes. Furthermore, the Sufi religiosity is rooted in the ideology of the wahdat-e wujūd, the unity of being. This ideology has been carved by Sufi poets, such as Shāh 'Abd al-Lațif (d. 1752).

For Shāh 'Abd al-Latịf, the final goal in life was the same as for all followers of religion: to be merged with God, through the guidance of a spiritual master. Shāh 'Abd al-Lațif was himself a follower of the jog $\bar{\imath}{ }^{18}{ }^{18}$ who were for him masters of renunciation. He praised them in his poetry and narrated how he performed pilgrimages in their company to important Hindu places, such as Dwarka or Hinglaj. In other words, the Sufi ideology in Sindh is an alternative religiosity, which does not prevent the acknowledgement of institutionalized Islam, from the five daily canonic prayers, to the performance of specific funerary rituals. Nonetheless, the Sufi ideology cleared a space beyond the formal belonging to a specific religion. Consequently, the Sufi could be Muslim or Hindu.

Most of the rituals performed at the Qadamgāh Imām 'Alī are enshrined in local Sufi religiosity. The main purpose of the vow (manat) is to create a formal link between the devotee and 'Alī. The ritual of manat is similar to those performed in the Qadamgāh Imām 'Alī and in the Sufi dargāhs. The first part involves actions that are supposed to purify the space. It starts with the lighting of candles (chirāgh), for the purification of the air, so a sacred space and time can be created. The purification continues with the burning of incense (agarbatti). The ritual is performed in the evening, and the favorite location for the ritual is the 'alam of 'Abbās.

After these two preliminary actions, the ritual itself can start. After the believer has made a vow, the ritual of tiding threads (dhägo) follows. The threads are attached to the main gates of the Qadamgāh, as well as to the shabìh of 'Alī, and near the 'alam of 'Abbās. When the wishes are made, worshippers untie the threads, and throw them into the river, or wear them around their necks. Another way to materialize the manat is to fix locks, especially to the zarịh of 'Abbās 'Alamdār. Similarly, they are fixed to the shabìh of 'Alī, and to the iron fence surrounding the 'alam of 'Abbās 'Alamdār. The duration of 

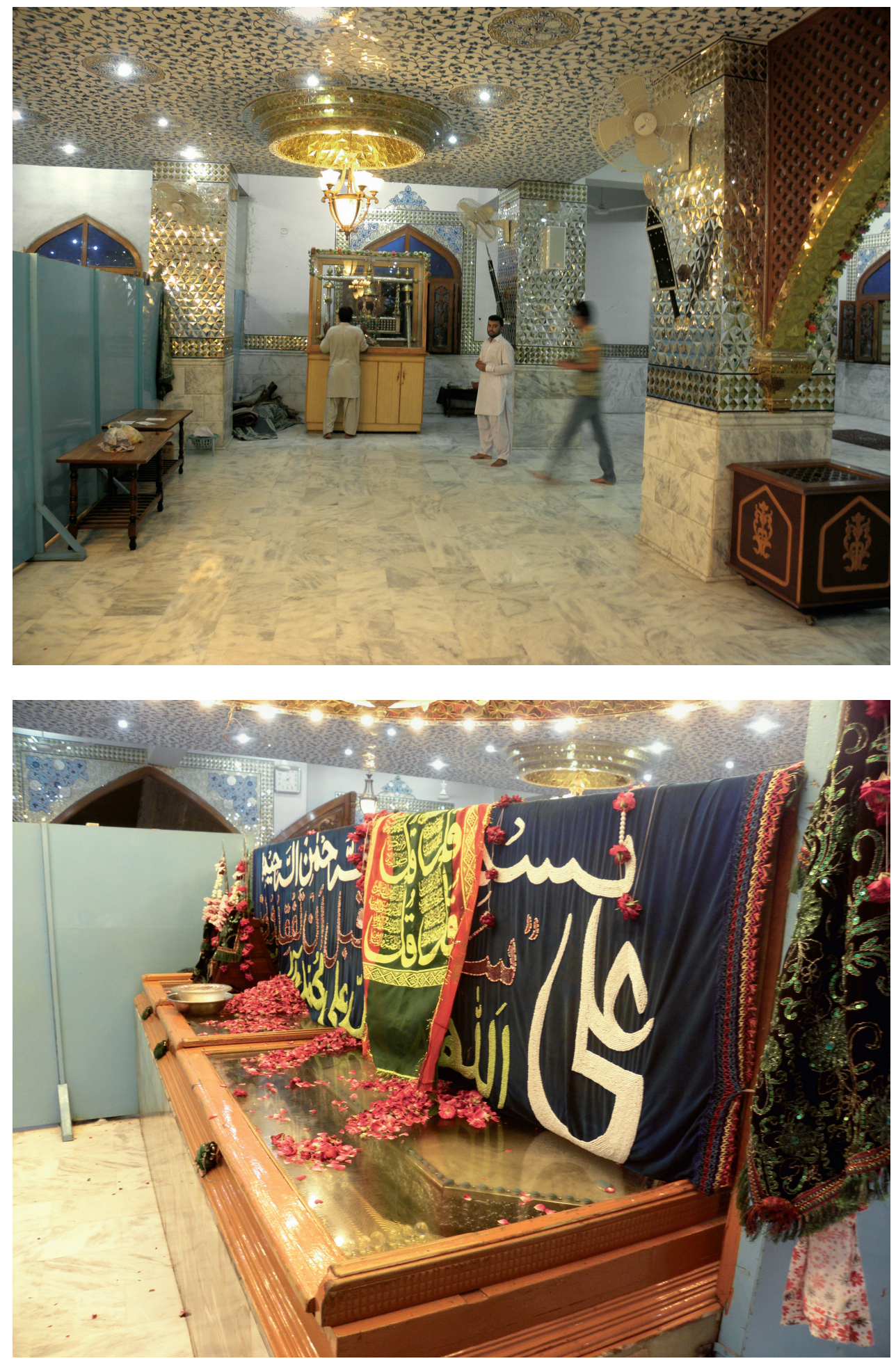

the ritual varies and depends on the devotees. Once the vow is fulfilled, the devotees bring gifts or nazrānas to the Qadamgāh. They are of different types, and include sweets or flowers, but the best gift for spiritual benefits (sawāb) is an offering of niy $\bar{a} z$, cooked food. ${ }^{19}$

Other rituals highlight the Shi'i identity of the Qadamgāh Imām 'Alī. Pilgrims attend lectures, for example, which are often held at the Qadamgāh Imām 'Alī. In this case, it works as an imāmbāara. According to the caretaker of the shrine many people have
FIGURE 5

The main room, where many different devices related to the Imams are exhibited, Qadamgāh Imām 'Alī, Hyderabad. On the left side, the palisade which separates men from women (C) MICHEL BOIVIN, 2013

FIGURE 6

The footprints of 'Alī in stone in Qadamgāh Imām 'Alī, Hyderabad (C) MICHEL BOIVIN, 2013 
converted to Islam through these lectures. The lectures include various topics on Islam. Some lectures on the twelve Imams also take place at the shrine. Another formal link between the Qadamgāh and Shici culture is revealed when the processions starting at the nook and corners of the city end or begin at the Qadamgāh (Bullo, 2013: 140).

\subsection{Polarization and Network: The Qadamgāh and the Shi i Processions}

The Qadamgāh Imām 'Alī plays a pivotal role in main Shici events, especially during the four main processions that are organized throughout the year: the 1oth Moharram for 'Ashūrā', the 2oth Safar for Chehlum, forty days after 'Ashūrā', the 8th Rabī' al-Awwāl for Chup Ta'ziya, ${ }^{20}$ and the 13 th Rajab for the Yawm-e 'Alī, commemorating 'Alì's birthday. During Tālpūrs' rule, there was only a short procession starting from the dargāh of Ashrāf Shāh and ending at a place named Fāqir jo Pị̣ (See fig. 6.c). Today, many different processions are organized in Hyderabad throughout the liturgical year, under the aegis of two leading associations (anjumān): the Anjumān-e Imāmiyya Sindh, founded in 1908, and the Anjumān-e Hyderī, founded in 1949. The first Anjumān is dominated by the Sindhis, while the second was created by the Mohājirs soon after they migrated from India to Pakistan. It is now mixed with Sindhis, Mohājirs, Punjabis and others, and the president of the Anjumān-e Hyderī is Nawāz Bhutțo. ${ }^{21}$

Both associations have been given permission by the Awqaf Department to organize the processions, and they have divided it accordingly; the Anjumān-e Hyderī organizes the 'Ashūrā' and Chup Ta'ziya, while the Anjumān-e Imāmiyya Sindh organizes Chehlum and Yawm-e 'Alī. There are many other local anjumāns operating in different neighborhoods (mohalla or pāro) of the city. At the Qadamgāh, some processions start from the site, while others end at it. But there are local processions that do not include it in their itinerary, or it is peripheral. For example, on the 7 th of Moharram, a procession starts from Imāmbārgāh Anjumān-e Safīna ${ }^{22}$ that reaches Fāqir jo Piṛ. It was on this day that Husayn and his companions were deprived of water, but in South Asia the wedding of Qāsim b. Hasan with Fāțima Kubra b. Husayn is commemorated. The Qadamgāh is not included in the itinerary, but many devotees collect mendī at Gul Shāh Pị to bring it to the Qadamgāh. In South Asia, the mendī or henna is the very symbol of wedding. ${ }^{23}$

On the 1oth Moharram, or 'Ashūrā', three main processions are organized. The first one starts from different areas in the city, such as Latifabad, Qasimabad, Makrani Paro, Husaynabad and Wahdat Colony. At 7:oo AM, they join the main procession that starts from the Qadamgāh. From there, they walk to Karbala Dadan Shah, named after the second president of the Anjumān-e Hyderī, following the same itinerary of the other processions. The second procession begins at Imāmbārgāh Gul Shāh and terminates at the Qadamgāh, thus following a different itinerary than the first one. The third procession starts at Syed Imām 'Alī Imāmbārāa and ends at the dargāh of Ashrāf Shāh, nearby the Pakka Qila. In all these processions, Zūl Jinnah and the 'Alam Pak, 'alam of 'Abbās, ${ }^{24}$ are exhibited, and the devotees perform the ritual flogging (mātam) at different stations along the road, but many go to the Qadamgāh to perform mātam.

For the Chehlum of 'Ashūrā', on the 2oth of Safar, a procession is organized that starts at the Qadamgāh and ends at Karbala Dadan Shah. Interestingly, during the procession, thousands of women pay homage at the Sarfarāz Kalhoṛo's shrine, before returning to the procession. ${ }^{25}$ After a short rule of only three years, Sarfarāz was martyred in 1775. The itinerary of the three processions is unchanged. From the Qadamgāh, the procession reaches Station Road before entering Khokhar Mohallah and then taking Lajpat Road, Saddar Bazar and Mohammad Ali Johar Road. Finally, it ends at Karbala Dadan Shah. Zūl Jinnah and replicas of coffins (tābūts) are carried around during the procession. 

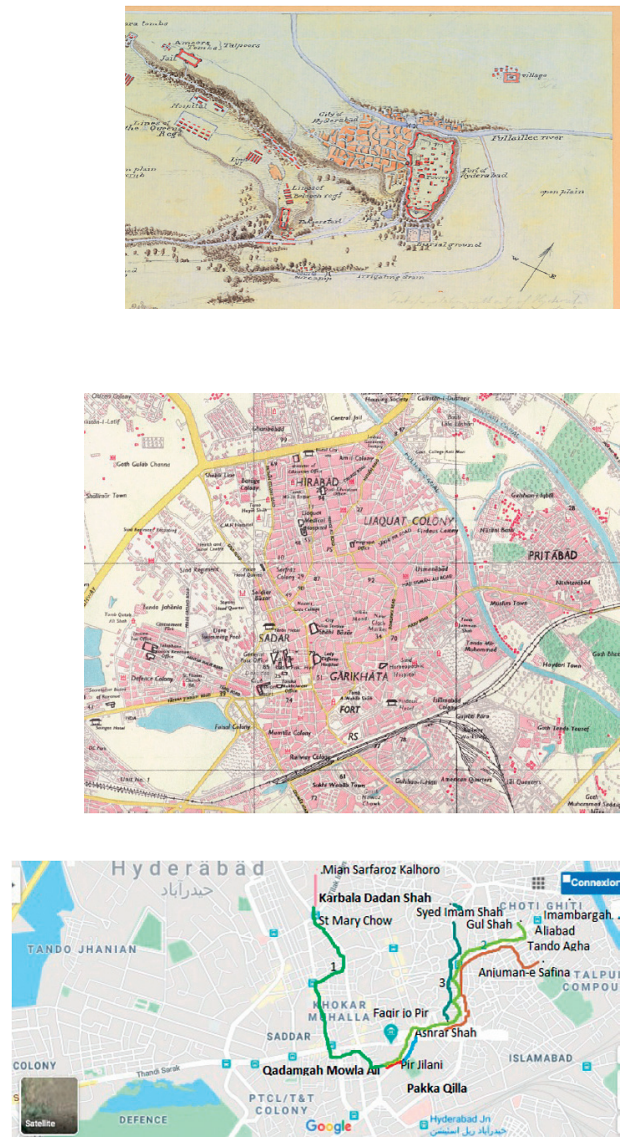

Blue: Tālpūr procession

Brown: local procession on 8th of Moharram Green: the first procession of 'Ashūrā', Chehlum and Yawm-e 'Alī (1)

Pale green: the second procession of 'Ashūrā' (2) Green-blue: the third procession of 'Ashūrā' (3) Red: the link between Qadamgāh with Pīr 'Abd al-Waḥab Jìlānī

Pink: supererogatory procession of women to Miyyān Sarfarāz Kalhoṛo
FIGURE 7.A

Map of Hyderabad (Sindh) and neighborhood. January $185^{2}$ by Henry Francis Ainslie (c. 1805-79), British Library, Shelf mark: WD2080; Item number: 2080 The Qila is in red, and the Mowlā jā Qadam is not indicated.

FIGURE 7.B

Sketch Map of Hyderabad, Survey of Pakistan

$\uparrow$ North $2 \mathrm{~cm}=500 \mathrm{~m}$

FIGURE 7.C

Itineraries and the polarity of the Qadamgāh

(C) MICHEL BOIVIN FROM GOOGLE MAP

For the Yawm-e 'Alī, which is the commemoration of 'Alī's birthday, the procession starts from the Qadamgāh Imām 'Alī. It then follows Station Road, Lajpat Road, Risala Road before entering the Karbala Dadan Shah (See 6.c). It is thus restricted to the old town between the Pakka Qila and the Kalhoro cluster. The different areas it crosses reveal the diversity of the population: the Khokhar Mohallah, from a Punjabi community, the Bohra Mohallah, from a Gujarati Isma'ili Shi'ite (non Aghā Khānī) community, and others. As in the Moḥarram processions, the sacrality of the Qadamgāh Imām 'Alì goes beyond the Shi'ite referent. The visitors belong to all the diverse communities that make modern Hyderabad: Sayyids, Shidis, ${ }^{26}$ Sunnis, and Hindus, as well as Christians.

A last point that should be highlighted is that the visitation to the Qadamgāh Imām 'Alī has been inserted into the Sufi pilgrimage circuit of the city of Hyderabad. As in most cities and towns of Sindh, all Sufi dargāhs form a kind of network, in which the dargāhs are classified according to a hierarchy derived from the order in which they are to be visited. ${ }^{27}$ In this respect, the Qadamgāh is connected by a narrow lane to an important dargāh: that of Pīr 'Abd al-Wahab Jīlānī. As his name reveals, he was a Qādirī, 
and the shrine was built in the time of the the Kalhoraans, in the seventeenth century. It is customary that believers who plan to go the Qadamgāh Imām 'Alī first go to Pīr 'Abd al-Waḥab Jīlānī to recite a fätiḥa (Bullo, 2013: 139). Today, his nickname is Mohäjir kā pōr, or the pir of the Mohājirs. It means that the dargāh should have been controlled by the Mohājirs.

The same custom should be followed for the Qadamgāh Imām 'Alī. Although it was probably installed after the dargāh of Pīr 'Abd al-Waḥab Jīlānī, it started a conversation between the two repertoires of Sufism and Shicism. The study of the processional pathways clearly shows how the Qadamgāh is geographically enshrined into a network of pirs and dargāhs.

We have now been able to retrace the different transformations of the Qadamgāh Imām 'Alī, and its very specific position between Shi ite and Sufi religiosity. We will continue with a more focused analysis of qadam as a religious object, and try to situate it in the debates on the construction of religiosity, particularly in South Asia, where all the major religions, Hinduism, Buddhism, Jainism and Sikhism, practice the veneration of footprints. After my proposition for a typology of footprints in Sindh, I will address a few main issues and explain how they are approached by scholars of Hinduism and Buddhism. It will allow me to summarize the issue of the qadams by locating them in the general grammar of Muslim devotion, and it allows me to highlight what is shared between and what is specific for $p \bar{a} d u k \bar{a}$ and qadams. In other words, I will gauge to some extend the qadam encounters of the Indic religious setup.

Two issues have our special attention. On the one hand, there is the question of the sensorial experience: does the qadam cause some specific sensorial experience? Or is this an experience similar to those caused by other relics? On the other hand, there is the question of the exact status of the qadams, in other words how are they relics and what kind of relics are they? Here we must consider the position of the qadams in relation to the question of iconicity and aniconicity. Jacob N. Kinnard, a specialist of Buddhism, has suggested that footprints could represent the unfinished transition between aniconic and iconic representations (Kinnard, 2014). According to Albertina Nugeteren, Vishnu's pādas replace statues, and they are both absence and presence, as well as form and formless (Nutgeren, 2018: 212). It is another interpretation of the presence in absence. Finally, she states that the footprints are semi-iconic (Nutgeren, 2018: 215). But before addressing these issues, I want to propose a tentative classification of the footprints in Sindh.

\subsection{The Footprints in Sindh: A Tentative Classification}

In Sindh, the veneration of footprints involves three sacred figures: 'Abd al-Qādir Jīlānī, 'Alī, and Muhammad. We already know about the importance of Jìlānī in Sindh, as well as that of the Qādiriyya. In the town of Hala, the footprints of Pīr Jīlānī can be found. This is interesting as Hala was a leading center of the Suhrawardiyya from the sixteenth century onward. It contains the dargāh of Makhdūm Nūḥ (died circa 1592), a Suhrawardī Sufi. We can propose the hypothesis that the creation of the Pīr Jīlānì jā Qadam may have been a response of the Qādirīs to the development of the Sohrawardis, through the radiation of Makhdūm Nūh. Consequently, the Qadam would function here as an instrument in the competition between two Sufi brotherhoods.

One last category of prints should be mentioned: those of the hooves of 'Ali's horse. ${ }^{28}$ In a qadamgāh near Kashan, in Iran, dated 1311, hoofprints of 'Alī's horse and camel, 
can be found, represented in earthenware (Flood, 2019: 241). As we have seen before, horses are also venerated, especially those of 'Alī and Husayn, named Duldul and Zūl Jinnah, as indicated by the many posters representing them. In Sehwan Sharif, where Lal Shahbaz retired, the chillagā $h^{29}$ contains the tracks of the hooves of 'Alì's horse. Notwithstanding, the Qadamgāh Imām 'Alī of Hyderabad stands out from all the others located in Sindh. For a long time, it was indeed the only one that was sheltered by a real mausoleum, and the other qadams are open spaces, generally established near the Sufi or Isma'ili dargāhs. ${ }^{30}$

In the case of the Qadamgāh Imām 'Alī, one can hardly make out the footprints, because there is only a vague form, which is said to be a footprint. A main characteristic is the size of the qadam: they are very big, maybe one meter long, which suggests that 'Ali was a giant. Of course, it is said that the size of 'Alī's footprints is a metaphor of his human qualities. The qadam in Makkli belongs to the third category. Here, the size is human, while the shape of the feet is well designed. Scholars classify the authenticity of qadams according to their shapes. The more shapeless the qadam is, the more authentic it seems to be, and the more stylized the qadam is, the more inauthentic it is considered to be. In this case, it means that the footprints were carved, more or less recently, and that they are clearly the work of an artisan.

\subsection{The Sensorial Experience of the Presence in Absence}

Of course, the final purpose of a visit to the Qadamgāh is to experience the sacred through the presence of a saint, a prophet or a god, an encounter with the divine. In this respect, another main distinction between the pāduka and the qadam is how they are used. For the $p \bar{a} d u k \bar{a}$, the ritual of touching is of primary importance, and probably more so than the act of seeing. According to Nugeteren "... this reaching out, kneeling and touching includes various physical gestures of devotion involving multiple senses and the entire human bodies" (Nutegeren, 2018, 213).

In the case of the Qadamgāh Imām 'Alī, the qadams are protected by a showcase (see above fig. 5), that allows the believer to see, but prevents him or her from touching the qadams. When was this set up? I cannot answer this question, but one can surmise it was possible to touch them in the past. As a matter of fact, in devotional rituals and actions pertaining to local Sufi piety, touching is a main gesture, a means to forward the sacred, the baraka. After touching a sacred object, the devotees will put their hands over their faces, literally smearing themselves with baraka. Some relics are covered with a showcase or even a silver leaf, such as the gulüband ${ }^{31}$ in Sehwan Sharif, and it is said it is for protection. As a matter of fact, it does not diminish the experience, because for the devotees, the relic is powerful enough to transmit the baraka to him/her across the "protection". Consequently, they do in fact perform the ritual act of touching.

The qadam is different if compared to other relics. The mantle of Muhammad can procure great spiritual merit. It can be seen as a medium, transmitting the baraka from his body to the believers though the act of touching. But with the qadam, it is a different kind of sensorial experience. First there is the function of medium; if the believer can touch the footprints, he or she will come in contact with 'Alī. But it goes even further: the trail left by 'Alī is evidence that HE WAS HERE. The qadam is thus an indisputable proof of his presence, despite his absence.

Once again, the act of seeing or visualizing is of primary importance, both in Muslim and Indic religious cultures. This is the transformative act that makes an absence present. The presence in absence is realized through the process of seeing and visualizing. I make here a distinction between both: seeing is the physical process, allowing someone to see something or somebody, while the visualization is the interiorization of the previous act, the act of seeing the spiritual reality of the person. Depending on the 
religious traditions, this reality can be named cosmic, esoteric, or mystic self, but in each case, it is located beyond the bodily shape of a person.

In Sindhi the act of both seeing and visualizing is described by two main terms: darshān and dīdār. These two terms belong to two different linguistic repertoires, as well as two different religious contexts. The term darshān, from Sanskrit, is especially used by the Hindus, while the term dìdār originates from Persian, and is mostly restricted to Muslim esotericism, both Sufi and Shici. Notwithstanding, in Sindhi, both are used indifferently in Sufi, as well as Isma'ili and Hindu terminology. There are many definitions of darshān/dīdār, but put briefly, it means "the visualization of the divine". This is the first step. The second step, the final goal of the believer, is the encounter with the divine. The act of visualization leads to this final step (see Ruffle's article in this volume).

\subsection{The Qadam as Relic}

How are qadams relics and what kind of relics are they? To answer these questions, I must try to create a typology of relics. I surmise that there are three main categories of relics: 1. Objects belonging to a god, a prophet, or a saint, such as clothes, arms, cups, and other items; 2. Human remains, such as heads, hairs etc.; 3. Footprints. On a ritual level, one can detect a number of differences within the worship of the pādukās. In the Qadamgāh Imām 'Alī circumambulation is not possible. While this is the main ritual in the Sufi dargāh, the agency of the qadams just makes this impossible. Another distinction is that in the Qadamgāh, there is gender segregation. Men and women are not allowed to pray together when facing the Qadamgāh. In fact, the most important space, the bigger one, is reserved for the men.

The qadam and the $p \bar{a} d u k \bar{a}$ also share features, such as for example the competition with other relics. In this regard in Indic context, the $p \bar{a} d u k \bar{a}$ can be seen as a murtī, a statue, while in Muslim context, this is not possible, even if figurative representations circulate, such as posters. Consequently, the competition that the qadam and the $p \bar{a} d u k \bar{a}$ faces, is not with identical relics. Indic temples are repleted with statues of gods and goddesses, gathered in a single temple. In a Muslim context, the competition would be more with other sites that contain relics, especially Sufi dargāhs. But as we saw in Hyderabad, as well as in many other cities such as Sehwan Sharif, there was a pretty harmonious combination of both repertoires that allowed these sites to be incorporated into a sacred itinerary.

Furthermore, if there is competition, it is good to remember that there are only a few qadams devoted to Sufis: most qadams are attributed to Imam 'Alī. Consequently, it is relevant to make clear that this specific category of relics is tightly framed and associated with a specific sacred figure of Muslim piety: that of 'Alī. It is well known that 'Alī embodied the best qualities a human can be gifted with: loyalty, courage, and righteousness. In other words, 'Alī is the perfect, exemplary Muslim, and as such, he is THE model, the mard-e Mardān, meaning the man, the human being par excellence. The qadam is the best relic, as through the presence in absence, it grants the believer his or her dearest wish: to meet 'Alī, the insān-e kāmil, the Perfect Man of esoteric Islam.

But even so, what was the need to create this form of relics, when others existed in Sufi mausoleums? Could this particularly powerful relic make up for a possible geographical remoteness from the most important holy places? This is certainly only a hypothesis, but it seems to me that the case of the Wakhan is significant in this respect. The Wakhan is a province located on the border of Afghanistan, Tajikistan, and Pakistan. The Wakhanis live in very hard-to-reach valleys, and they are mostly Isma'ili Shicites. Locally, it is known as qadamgāh-e pìrān, or the "place of saints' footprints." There is also another shrine, the farmān khānā, or "The House of Orders," where, among other relics, 
Holy Hair (Mui Mubārak) of the present Imam, the fourth Aghā Khān, Shāh Karīm, as well as his picture (aks-i mubārak) are kept (Iloliev, 2008: 65).

Iloliev observed how this mausoleum has changed since the late nineteenth century. The architecture has been modernized, and many relics have been added over the years, as if this build-up has strengthened the spiritual influence of the site. Nonetheless, the most amazing place in Wakhan is a shrine devoted to the qadamgāh of Fātima. It contains a sanatorium with two pools of natural hot spring water with miraculous powers. The members of the local government own cottages nearby, as if the place were a resort for tourists. (Iloliev, 2008: 66-7). Local people firmly believe that the site is frequented by the spirit of Fātima, and a hole with warmer water is said to be her womb.

In a Muslim context, where iconographic representation of the sacred is explicitely forbidden by the Quran, the qadam as relic is singular. It is not the figurative representation of 'Alī, although we can find many in the bazars, around the dargāhs and the qadams. It is not a sacred object, a relic, which is blessed and considered as a baraka medium, for any reason. In itself, the qadam is not an object, as it is hollow. The qadam allows the believer to act in a measured and controlled transgression, because of the Quranic interdiction of idolatry, and because it simultaneously puts him in the presence of the most sacred character of Islam after Muhammad. Consequently, the qadam is an iconic representation of iconicity, thanks to its liminal status.

Like the $p \bar{a} d u k \bar{a}$, the qadam is polyvalent. They are objects of political alliance, polarization of devotion, and social control, as well as ethnic integration. I have suggested that the installation of the qadam in a shrine in Hyderabad could have resulted from an attempt to create a new devotional Shici pole, as Shāh 'Abbās operated with the Qadamgāh Imām Reżā near Nishapur. This attempt was cut short by the British conquest.

The veneration of footprints is a well-spread tradition all over South Asia, and shared by the different religions. The footprints belong to the subcategory of bodily relics, but work on a specific register: the expression of a presence through absence. The absence of the body is compensated by the presence of footprints. While the saintly character is obviously absent, there is a material trace that proves he has been present, and it creates a peculiar form of presence: the presence in absence. The aim of this chapter was manyfold. It shows that apart from the political and social roles that have been attributed to the qadam by different components of local society, its growing success also comes from the bridging of basic devotion of the local Sufi pattern, with the display of an authentic Shi'i identity.

The Mowlā jā Qadam started as a symbol of the political alliance between the Qajars and the Tālpūrs, and it was for them probably a tool for the reinforcement of their legitimacy as Shici rulers. However, it was only just before the British conquest that the last Tālpūr decided to build a shrine and to exhibit the sacred relics. Later, the partition caused a significant renewal of the population of Hyderabad; although the population was first predominantly Hindu (2/3), it became predominantly Mohājir. Riots between Mohājirs and Sindhis occurred in the wake of the partition and, although the onomastic details are not known, the Mowlā jā Qadam was transformed into the Qadamgāh Imām 'Alī.

Today, the Qadamgāh Imām 'Alī hosts many different relics related to the Ahl-al Bayt, but the most important are those belonging to 'Alī, Husayn, 'Abbās 'Alamdār and 
'Alī Asgar. It works on two different registers: everyday life is framed according to the Sufi repertoire of devotion, while the main events of the Shici liturgical year provide another repertoire of devotion. Daily life is made of manat, when people light chirāgh, tie threads and fix locks. These "ritual" actions are quite common in a Sufi context. The second register is more related to Shi ite events, like for example the Moharram processions. Finally, lectures on different "Islamic" topics are delivered at the Qadamgāh Imām 'Alī. Informants mentioned repeatedly that Christians and Hindus also visit, and that after listening to them, some have converted to Islam. This last aspect of the Qadamgāh Imām 'Alì is a topic for future research.

In conclusion, the religious identity of the Mowlā jā Qadam is complex. It performs certain functions of the pir, but must be considered as a dargāh, according to the common rituals that are performed there. It is a centerpiece of the Shi ite processions, and the $z \bar{a}$ kirs used to deliver sermons on different issues related to the Moharram tragedy, as well as on other issues. It is thus relevant to speak of a liminal status, because it is located at the meeting point of Sufism and Shi ism. It is this liminal status that allows it to attract different categories of pilgrims. On the other side, we can also observe that the Qadamgāh has now surpassed political issues, which characterized the first period of its history, but also ethnic issues. As a result, although it retains a distinct identity, the Qadamgāh has been absorbed into the local religiosity imbued with Shicism and Sufism. In other words, it still works as a sample, among others, of the shared religious legacy of Sindh.

\section{About the Author}

Michel Boivin is the author and editor of fifteen books. His most recent book is entitled The Sufi Paradigm and the Makings of a Vernacular Knowledge in Colonial India: The Case of Sindh (1851-1929) (New York, Palgrave McMillan, 2020).

\section{Bibliography}

Advani, A.B. (1938). The Holy hair at Rohri. Journal of Sind Historical Society 3 (3), pp. 69-70.

Bellamy, Carla (2011). The Powerful Ephemeral. Everyday Healing in an Ambiguously Islamic Place. Berkeley and Los Angeles: University of California Press.

Bohra, Qammaruddin (2000). City of Hyderabad, Sindh (712-1947). Karachi: Royal Book Company. Boivin, Michel (2015). Artefacts of Devotion: The Sufi Repertoire of the Qalandariyya in Sehwan Sharif, Sindh (Pakistan). Karachi: Oxford University Press.

Boivin, Michel (2020). Sufism and Shi'ism in South Asia: shahadat and the Evidence of the Sindhi marthiya, in Denis Hermann and Mathieu Terrier (eds). Shii Islam and Sufism. Classical Views and Modern Perspectives. London: I.B. Tauris in association with the Institute of Ismaili Studies, pp. 225-54.

Bullo, Momin (2013). Hyderabad Revisited. Hyderabad/Karachi: Commissionerate of Hyderabad/ Endowment Fund Trust for Preservation Heritage of Sindh.

Centlivres Pierre et Centlivres-Demont, Micheline (1997). Imageries populaires en Islam. Geneva: Georg Editeur.

D'Souza, Diane (1998). In the Presence of the Martyrs: The Alam in Popular Shii Piety. Muslim World, 88 (1), pp. 67-80.

Flood, Finbarr Barry (2019). Technologies de dévotion dans les arts de l'Islam. Pèlerins, reliques et copies. Paris: Editions Hazan/Musée du Louvre. 
Ganem, Jacqueline Louise (2006). Traces of the Prophet: A Study of Eighteenth-Century Qadam Rasul Shrines in the Indian Subcontinent. PhD diss., University of Virginia.

Goldziher, Ignaz (1971). Muslim Studies (Muhammadische Studien), ed. S.M. Stern, tr. From German by C.R. Barber and S.M. Stern, vol. 2. London: George Allen \&Unwin.

Green, Nile (2012). Making Space. Sufis and Settlers in Early Modern India. New Delhi: Oxford University Press.

Hasan, Perween (1993). The Footprint of the Prophet. Muqarnas 10, pp. 335-43.

Iloliev, Abdulmamad (2008). Popular Culture and Religious Metaphor: saints and shrines in Wakhan region of Tajikistan. Central Asian Survey 27 (1), pp. 59-73.

Kalhoro, Zulfiqar Ali (2018). Archaeology, Art and Religion in Sindh, Karachi, Culture, Tourism, and Antiquities Department.

Khwaja, G.S. (1996). Prophet's Foot Prints: A Study through Epigraphs and Literature. Journal of the Epigraphical Society of India 22, pp. 61-3.

Kinnard, Jacob N. (2014). Places in Motion. The Fluid Identities of Temples, Images, and Pilgrims. Oxford and New York: Oxford University Press.

Kuggle, Scott (2007). Sufis and Saints' Bodies. Mysticism, Bodilyity, and Sacred Power in Islam. Chapel Hill: The University of North Carolina Press.

Mahdizadeh, Sara (2013). The role of religion and tradition in garden conservation: A case study of Qadamgah tomb-garden, Neyshabur, Iran. Exegesis 2, pp. 14-23.

Meri, Josef W. (2010). Relics of Piety and Power in Medieval Islam. Past and Present, Supplement 5 , pp. $97-120$.

Nugteren, Albertina (2018). Bare Feet and Sacred Ground: Visnu Was Here. Religions 9 (7), pp. 208-28.

Ruffle, Karen (2017). Presence in Absence: The Formation of Reliquary Shicism in Qutb Shahi Hyderabad. Material Religion 13 (3), pp. 329-53.

Sadique, Salma, Ghulam Mustafa Gaho, Ahmed Husayn Shah Bukhari (2015). Mannat associated to folk Belief at Qadam Gah Mola Ali K. W. (Foot Prints of Hazrat Ali K.W). Hyderabad. Mystic Thoughts: Research Journal of Sufism and Peace, Supplement to Vol. 1 (1), pp. 51-9.

Smyth, J.W. (1919). Gazetteer of the Province of Sind: B. Bombay: Government Central Press.

Trivedi, Madhu (2010). The Making of the Awadh Culture. Delhi: Primus Books.

Verkaaik, Oskar (1994). Migrants and Militants. Fun and Urban Violence in Pakistan. Princeton and Oxford: Princeton University Press.

Welch, Anthony (1993). The Shrine of the Holy Footprint in Delhi, Muqarnas 14, pp. 166-78.

Notes

1 In an article published in 2003 (reprinted in his Sufis and Settlers in Early Modern India in 2012).

2 The imāmbārā (or imāmbārgāh) is the building where the artifacts paraded for Moharram are kept, and where mourning gatherings known as majlis are organized.

3 I focus on Hyderabad in Sindh, today in Pakistan. When I mention Hyderabad in Deccan, I shall write "Hyderabad, Deccan". For the first one, only write "Hyderabad".

4 Guru Nanak (1469-1539) was the first guru and the founder of the Sikh religion. During his lifetime, Babur (1483-1530) founded the Moghul dynasty.

5 The nawāb was the governor of a province under the Mughals. After the empire collapsed, some sovereigns of the successor states kept the title although they were independant rulers. According to one of my informants in Hyderabad who draws upon family tradition, the gift was granted by Fath 'Alī Shāh Qājār to Ghulām 'Alī Tālpūr in $18 \circ 3$.

6 Unfortunately, the sources I have used do not allow me to firmly state there was a direct link between the Qadamgāh Imām Reżā near Nishapur, and the Mowlā jā Qadam of Hyderabad. But knowing the importance of the first, I suppose it could have been an inspiration for the second. For Sara Mahdizadeh, the Qadamgāh Imām Reżā is "a physical representation of the belief of Iranians towards their eighth Imam.” A main difference between both qadams is that Imam Reżā's one is adorned with a garden, which is for the same author "an association with the Paradise 
garden of the Hereafter described in the Qur'an" (Mahdizadeh, 2013: 14). Today, the Mowlā jā Qadam is located in a very congested area of Hyderabad but, as can be seen on the $185^{2}$ map, it was close to a wooded area with a pool when it was built shortly before the British conquest (see below 6 a). However, this is only an inference, because Henry Francis Ainslee, the British officer who carried out the map, was not at all interested, like most British soldiers, in representing places of worship. The details provided here on the origin of the Mowlā jā Qadam come from interviews I conducted in 2015 with several members of the Tālpūr royal family, in Hyderabad and Khairpur. I want to express my warmest thanks especially to Prince Mehdī Reżā Khān Tālpūr, the youngest son of Mīr George 'Alī Murād Khān Tālpūr, the last ruler of Khairpur. The Sayyids are the descendant of the Prophet of Islam, Muhammad. In Muslim societies of South Asia, they are at the top of the social hierarchy. For more details on the Pakka Qila and the Kacha Qila, see Bullo (2013).

10 In South Asia, the major pilgrimage is the hajj, when pilgrims go to Mekka and Medina, and the visitation of the saints' tombs is known as minor pilgrimage or ziyārat.

11 Before the British conquest of Sindh in 1843, Sindh was a confederate State ruled by three mìrs (from Arabic $\bar{a} \bar{m} \bar{\imath}$ ), who were settled in Hyderabad, this one having supremacy over the other two, Mirpur Khas and Khairpur. The mir of Khairpur negociated with the British, who allowed him to keep his state. From 1843 onwards, the Shi'ite patronage was held by the Tālpūr mìrs of Khairpur. See Boivin (2020).

12 We do not know if this expression was used during the Tālpūrs' rule, but it is used today (Sadique, Gahor and Bukhari, 2015: 51). Najaf is the most important sacred city of the Shicites, as it is where 'Alì's tomb is located.

13 I was not able to find out when this change occurred exactly, but for sure after the partition.

14 The meaning of the words zarịh and shabih differ from country to country. In Sindh, the zarịh is a decorative grave covering and it is used for the whole replica of a tomb, while the shabih, which was initially an image, now has the same meaning. In fact in Sindh, both words are used together to refer to a miniature shrine.

'Alī Asgiar was the youngest son of Imam Husayn. He died at Karbala, in the arms of his father.

Kot Diji is a location close to Khairpur. It is the place where the last mir of the princely state of Khaipur, Mīr George 'Alī Murād Khān Tālpūr, currently lives in a white palace.

17 Awadh was a Princely State of North India, suppressed by the British in 1856 . Before, it was ruled by a Shi'ite dynasty of nawäbs, with Lucknow as the capital.

18 The jogi is a main figure of Sufi poetry in Sindhi. It is the vernacularized form of the Sanskrit yogī, and it refers to the Shivaite ascetics named Nāthpanthīs.

19 I have visited the site several times since early 20oos. Nevertheless, my observations are mostly the result of fieldwork in 2013. See also Sadique, Gaho, and Bukhari (2015), and Kalhoro (2018).

20 The Chup Ta'ziya (the silent ta'zia) procession commemorates the death of the eleventh Imam Hasan al-'Askarī. It is said to have started in Lucknow, and the Shi'ites who migrated from there brought this tradition with them to Sindh. It is the last procession of the mourning period that begins with Moharram. Hasan al-'Askarī is said to have been poisoned in 874 by the 'Abbasids. He was the father of the twelveth Imam who is the coming mahdī for the Shi'ites.

21 Nawāz Bhuțțo belongs to the Bhuțtos, a Sindhi "tribe," some of whose members ruled Pakistan in the 1970s and the 199os. Zulfiqār 'Alī Bhuțto (1916-1978) was Prime Minister and President of Pakistan, and his daughter Benazīr Bhuțțo (1954-2017) was Prime Minister twice. The first was overthrown by general Żiyāa al-Haqq and hanged after a mock trial, while his daughter was killed in a bomb blast. The anjumān manages the Jama'itiyyān jo Pị̣ Imāmbārāa, which would have been created in 1909 in the area named Tando Agha.

23 During the anual festival (melā) in Sufi dargāhs, a procession of mendī is similarly organized, to symbolize the "mystical wedding" ( 'urs) of the Sufi with God.

24 Zül Jinnah is the name of Husayn's horse, who is an object of veneration in South Asia, as the posters sold in bazars demonstrate (Centlivres and Centlivres-Demont, 1997: 45-47). The 'Alam Pak is the name given to 'Abbās's standard. 'Abbās was the half-brother of Husayn and he was killed on the 1oth of Moharram, while he was providing water to Husayn, and his family and partisans. On the veneration of 'alams in South Asia, see D'Souza (1998).

25 While he was the king of Sindh, Miyyān Sarfarāz Kalhoṛo was arrested and confined to Pakka Qila, before he was murdered in cold blood on the 2oth of Safar, 1189, or April 21, 1775, by order of his uncle Miyyān Ghulām Nabī Khān. He is thus a shāhid. Nevertheless, it is unknown how his shrine became a place of pilgrimage for women who performed the same Sufi-like rituals there. In his book on Hyderabad, Bohra classifies Sarfarāz's shrine both as a pị and a dargāh (Bohra, 2000: 53, 59).

The Shidis or Sidis are the descendants of slaves who were brought from Eastern Africa to India. Slavery was abolished after the British conquest. The Shidis have a very low status, and mostly 
worked as servants, but they also played another role in Sindhi society because of their musical skills. They often play the drums during Moharram processions, for example.

27 About the hierarchy and the network made by the Sufi dargāhs, see Boivin (2015). Nevertheless, the pilgrims are free to build their own hierarchy and order for the visitations of the sacred sites.

28 The hoofprints of 'Ali's horse is another common topic, but neglected by researchers. It is for example an element of the Husayn Tekri, see Bellamy (2011), 46. See also Flood (2019).

29 The chillaga $a$, literally "the place of forty," is the place where a Sufi ascetic is in retirement, for the practice of austerities. It is supposed to be 40 days long.

30 Another qadamgāh, a mausoleum, was built very recently in Makli, near Thatta. It is named Qadamgāh Mowlā 'Alī, or Jalwagāh Imāmīn (The Splendid Place of the Imam), and is under the management of the Anjumān-e Dār-e Panjtan from Thatta.

31 The gulüband, from an Urdu term meaning "necklace", is a big stone hanging from a corner of the catafalque of La'l Shahbāz Qalandar's tomb in Sehwan Sharif. It is said it was given to Imam Zayn al-'Ābidīn for travelling by foot from Karbala to Damascus. The weight of the stone he had tied around his neck forced him to walk bent over in humiliation. See Boivin (2015). 